\title{
Estimation of Chilling and Heat Requirements of Some Persian Walnut Cultivars and Genotypes
}

\author{
Asadolah Aslani Aslamarz, Kourosh Vahdati ${ }^{2}$, and Majid Rahemi ${ }^{1}$ \\ Department of Horticulture, College of Abouraihan, University of Tehran, \\ Tehran, Iran
}

\section{Darab Hassani \\ Department of Horticulture, Seed and Plant Improvement Institute, Karaj, Iran}

Additional index words. chilling requirement, heat requirement, walnut, frost, adaptation, acclimation

\begin{abstract}
The objective of this work was to determine the chilling and heat requirements of Persian walnut cultivars and genotypes using excised twigs. The experiment was carried out from Nov. 2006 and 2007 to Mar. 2007 and 2008. One-year-old twigs were prepared from four cultivars and four domestic genotypes of Juglans regia L. After leaf fall, the twigs were taken and placed in plastic bags and kept at $4 \pm 1{ }^{\circ} \mathrm{C}$ to stimulate 400 to 1500 chilling hours. After chilling, the excised twigs were transferred to the greenhouse with a natural photoperiod and a temperature from 18 to $27^{\circ} \mathrm{C}$. The evaluation of budbreak was made three times a week and the number of accumulated growing degree hours $\left({ }^{\circ} \mathrm{C}\right)$ was determined until the buds reached the balloon or green tip stage. The chilling requirements were lowest $(400 \mathrm{~h})$ for catkins and highest $(1000 \mathrm{~h})$ for lateral buds. The Serr cultivar and ' $Z_{30}$ ' genotype had the lowest chilling requirements ( 650 and $650 \mathrm{~h}$ ). 'Lara', ' $Z_{63}$ ', ' $Z_{53}$ ', 'Pedro', and ' $Z_{67}$ ' showed intermediate chilling requirements with values of $900,900,800,750$, and $750 \mathrm{~h}$, respectively. Finally, 'Hartley' completed its dormancy after an accumulation of $1000 \mathrm{~h}$, being the walnut cultivar with the highest chilling requirement in our study. As the final result, the cultivars and genotypes were classified into three groups based on their heat requirements: low requirement (' $Z_{30}$ ' and 'Serr'), medium requirement (' $Z_{53}$ ', ' $Z_{67}$ ', 'Lara', and 'Pedro'), and high requirement ('Hartley' and ' $\mathrm{Z}_{63}$ ').
\end{abstract}

Adaptation is a concept related to how plants can survive and reproduce in a specific environment (Hill et al., 1998), and it is reflected in the synchronization between the development stages and climate (Dietrichson, 1964). Chilling requirement is an aspect necessary to ensure that the plants are adapted to the appropriate area. Dormancy and freezing tolerance are the main mechanisms developed against very cold conditions, although they could be independent (Irving and Lamphear, 1967). Freezing tolerance cannot be developed adequately without growth cessation (Fuchigami et al., 1971), which marks the onset of dormancy. The interest in understanding the mechanism of dormancy set and release is mainly based on the necessity of manipulation of the dormant period to avoid spring frost damage (Faust

Received for publication 8 Dec. 2008. Accepted for publication 16 Mar. 2009

We thank the University of Tehran and Iranian National Science Foundation (INSF) for providing support for this research.

${ }^{1}$ Professor of Pomology at Department of Horticulture, Faculty of Agriculture, Shiraz University and Adjunct Professor at the Department of Horticulture, College of Abouraihan, University of Tehran.

${ }^{2}$ To whom reprint requests should be addressed; e-mailkvahdati@ut.ac.ir.
The study of the phenological behavior of crops, as part of a well-characterized environment, is important both to obtain satisfactory production and to determine the most suitable agronomic techniques (Valentini et al., 2001). In this way, if a cultivar is established in an area where its chilling requirements are not satisfied adequately, the vegetative and reproductive growth of the cultivar will be affected negatively (Black, 1952; Coville, 1920; Ruck, 1975; Samish, 1954; Weldon, 1934). On the contrary, in the case of a cultivar with low chilling requirements growing in cold winter areas, the blooming happens too early because the chilling requirement is quickly satisfied (Scorza and Okie, 1990). Furthermore, studies concerning chilling and heat requirements are thus of special interest in these species, being very important for the choice of parents in breeding programs looking for late-flowering cultivars (Spiegel-Roy and Alston, 1979). When the chilling requirement is satisfied, blooming will start. Early blooming increases the likelihood of damage by late winter or early spring frosts. The time of full bloom depends on two factors: the chilling requirements and growing degree hours Celsius $\left(\mathrm{GDH}^{\circ} \mathrm{C}\right)$ required after endodormancy for reaching full bloom (Raseira, 1986).

The risks related to the lack of knowledge for the heat requirements of walnut cultivars is less than the chilling requirement, but the knowledge will provide us with more possibilities for the management of this crop so that cultivars with low chilling requirements but high heat requirement could be cultivated in relatively cold areas (Citadin et al., 2001). Methods for determining the heat requirements of blooming have been developed (Richardson et al., 1974). These methods essentially consist of establishing the heat accumulation, above a threshold, to which a et al., 1997). Dormancy has a significant economic impact on the maintenance and production of herbaceous and woody plants (Fennell, 1999).
Table 1. Chilling requirement of Persian walnut cultivars and genotypes (hours below $7{ }^{\circ} \mathrm{C}$ ) to reach $50 \%$ of lateral and terminal buds and catkins to the balloon or green tip stage in 2 successive years. ${ }^{2}$

\begin{tabular}{|c|c|c|c|c|c|c|c|}
\hline $\begin{array}{l}\text { Cultivars and } \\
\text { genotypes }\end{array}$ & Years & Lateral bud & Mean & Terminal bud & Mean & Catkin & Mean \\
\hline \multirow[t]{2}{*}{$\overline{Z_{30}}$} & 2006 & $600 \mathrm{e}^{\mathrm{y}}$ & 650 & $500 \mathrm{~d}$ & 550 & $400 \mathrm{~d}$ & 400 \\
\hline & 2007 & $700 \mathrm{~d}$ & & $600 \mathrm{e}$ & & $400 \mathrm{~d}$ & \\
\hline \multirow[t]{2}{*}{$Z_{67}$} & 2006 & $800 \mathrm{c}$ & 750 & $800 \mathrm{~b}$ & 700 & $600 \mathrm{~b}$ & 600 \\
\hline & 2007 & $700 \mathrm{~d}$ & & $600 \mathrm{e}$ & & $600 \mathrm{~b}$ & \\
\hline \multirow[t]{2}{*}{$Z_{53}$} & 2006 & $800 \mathrm{c}$ & 800 & $800 \mathrm{~b}$ & 750 & $700 \mathrm{a}$ & 650 \\
\hline & 2007 & $800 \mathrm{c}$ & & $700 \mathrm{~d}$ & & $600 \mathrm{~b}$ & \\
\hline \multirow[t]{2}{*}{$Z_{63}$} & 2006 & $900 \mathrm{~b}$ & 900 & $700 \mathrm{c}$ & 750 & $700 \mathrm{a}$ & 650 \\
\hline & 2007 & $900 \mathrm{~b}$ & & $800 \mathrm{c}$ & & $600 \mathrm{~b}$ & \\
\hline \multirow[t]{2}{*}{ Serr } & 2006 & $700 \mathrm{~d}$ & 650 & $700 \mathrm{c}$ & 650 & $400 \mathrm{~d}$ & 450 \\
\hline & 2007 & $600 \mathrm{e}$ & & $600 \mathrm{e}$ & & $500 \mathrm{c}$ & \\
\hline \multirow[t]{2}{*}{ Hartley } & 2006 & $1,000 \mathrm{a}$ & 1,000 & $900 \mathrm{a}$ & 950 & $700 \mathrm{a}$ & 750 \\
\hline & 2007 & $1,000 \mathrm{a}$ & & $1,000 \mathrm{a}$ & & $800 \mathrm{a}$ & \\
\hline \multirow[t]{2}{*}{ Lara } & 2006 & $900 \mathrm{~b}$ & 900 & $900 \mathrm{a}$ & 900 & $700 \mathrm{a}$ & 750 \\
\hline & 2007 & $900 \mathrm{~b}$ & & $900 \mathrm{~b}$ & & $800 \mathrm{a}$ & \\
\hline \multirow[t]{2}{*}{ Pedro } & 2006 & $800 \mathrm{c}$ & 750 & $500 \mathrm{~d}$ & 600 & $500 \mathrm{c}$ & 500 \\
\hline & 2007 & $700 \mathrm{~d}$ & & $700 \mathrm{~d}$ & & $500 \mathrm{c}$ & \\
\hline \multicolumn{8}{|l|}{ Difference } \\
\hline \multirow[t]{2}{*}{ between years } & 2006 & $\mathrm{a}$ & & & & & \\
\hline & 2007 & $\mathrm{~b}$ & & & & & \\
\hline
\end{tabular}

${ }^{\mathrm{z}}$ Each value is the mean of three replications and eight cuttings per plot.

${ }^{y}$ Means in each column followed by the same letter are not significantly different according to Duncan's multiple range test $(P \leq 0.01)$. 
Table 2. Range of chilling accumulation at which different Persian walnut cultivars and genotypes that exposed to various chilling temperatures from 400 to 1500 showed higher than $80 \%$ of the percentage of lateral, terminal, and catkins budbreak in 2 successive years.

\begin{tabular}{lcr}
$\begin{array}{l}\text { Cultivars and } \\
\text { genotypes }\end{array}$ & Years & $\begin{array}{r}\text { Range of chilling } \\
\text { accumulation }\end{array}$ \\
\hline$Z_{30}$ & 2006 & $900-1,500$ \\
& 2007 & $800-1,500$ \\
$Z_{67}$ & 2006 & $1,100-1,400$ \\
& 2007 & $1,200-1,300$ \\
$Z_{53}$ & 2006 & $1,000-1,500$ \\
& 2007 & $900-1,500$ \\
$Z_{63}$ & 2006 & $1,400-1,500$ \\
& 2007 & $1,300-1,500$ \\
Serr & 2006 & $1,100-1,400$ \\
& 2007 & $1,000-1,500$ \\
Hartley & 2006 & $1,400-1,500$ \\
& 2007 & $1,300-1,500$ \\
Lara & 2006 & $1,100-1,400$ \\
& 2007 & $1,100-1,500$ \\
Pedro & 2006 & $1,300-1,500$ \\
& 2007 & $1,100-1,300$ \\
\hline
\end{tabular}

tree is exposed from breaking of dormancy until flowering date.

The chilling requirements for the termination of endodormancy (rest) were studied by many researchers (Chandler et al., 1937; Coville, 1920; Molisch, 1908). There are several methods for estimation of chilling requirements of plants such as using detached twigs (Citadin, 1999; Citadin et al., 1998; Herter et al., 2000), individual buds (Bianchi et al., 2000; Herter et al., 1992), and plants in containers (Camelatto et al., 2000; Citadin et al., 2001).

Each tree species has a specific chilling requirement that is related to the accumulated hours below a chilling temperature threshold or to cumulative chill unit, which are hours that are weighted for temperature effective- ness for breaking dormancy (Erez et al., 1979; Weinberger, 1950). Although it has been mentioned that many walnut cultivars require $\approx 400$ to $1500 \mathrm{~h}$ temperature below $7^{\circ} \mathrm{C}$ to fulfill chilling requirements (Chandler et al., 1937), the available data for the chilling and heat requirements of walnut cultivars, especially for domestic walnut genotypes, are scarce. Therefore, the aim of this investigation, in 2 successive years, was focused on calculation of chilling and heat requirements to break bud dormancy of some cultivars and domestic walnut genotypes using 1-year-old twigs picked in the fall. Hence, the information obtained will provide better understanding of chill and heat requirements of walnut, which will be useful for best cultivation of the cultivars in the proper region.

\section{Materials and Methods}

Plant material collection. In Nov. 2006 and 2007, after leaf fall and before chilling accumulation, 1-year-old twigs were randomly collected from eight trees, 14 years old, of Serr, Pedro, Hartley, and Lara cultivars and ' $Z_{63}$ ', ' $Z_{53}$ ', ' $Z_{30}$ ', and ' $Z_{67}$ ' domestic promising genotypes that are being evaluated as potential cultivars in a breeding program from the experimental orchard of the Horticulture Department of the Seed and Plant Improvement Institute, Karaj, Iran.

Chilling treatment in the laboratory. The twigs were cut into 288 cuttings $20 \mathrm{~cm}$ long for each cultivar and genotypes (2304 twig totally) and transferred to the laboratory. Only one lateral and terminal bud and one catkin in their apical position were conserved, whereas the other buds were eliminated. After disinfection with Captan (Bayer Co.) $4000 \mathrm{ppm}$, a group of 20 cuttings were wrapped in moistened cheesecloth and placed in a plastic bag to prevent dehydration during treatments and exposed to low temperature $\left(4 \pm 1{ }^{\circ} \mathrm{C}\right)$ to simulate 400 to $1500 \mathrm{~h}$ with 100-h intervals.

Budbreak in the greenhouse. After chilling, the excised twigs were placed with their basal ends in distilled water and forced to grow in the greenhouse with a natural photoperiod and varied temperature between 18 and $27^{\circ} \mathrm{C}$. The basal ends of the cuttings were cut three times a week (Citadin et al., 1998) and the water was replaced daily. Evaluation of budbreak was done three times a week for the number of buds reaching the balloon or green tip stage (Citadin et al., 2001). The accumulated $\mathrm{GDH}{ }^{\circ} \mathrm{C}$ (Richardson et al., 1974) from the stage when the twigs were transferred to the greenhouse until $50 \%$ of buds reached the balloon or green tip stage was determined. One $\mathrm{GDH}{ }^{\circ} \mathrm{C}$ is defined as $1 \mathrm{~h}$ at the temperature $1{ }^{\circ} \mathrm{C}$ above the base temperature of $4.5{ }^{\circ} \mathrm{C}$. GDH ${ }^{\circ} \mathrm{C}$ was calculated from hourly temperature between 4.5 and $25^{\circ} \mathrm{C}$ and all temperatures above $25^{\circ} \mathrm{C}$ were considered equal to $25^{\circ} \mathrm{C}$.

Experimental design and statistical analysis. The experiment was conducted in a completely randomized design with three replications and eight cuttings per plot. Correlation coefficients between chilling and heating requirements of the cultivars and genotypes were determined using Pierson ranked-order correlation. Data were analyzed using SAS Software (SAS Institute, Inc., 2002). Means with significant differences were compared using Duncan's multiple range test at $P \leq 0.01$.

\section{Results and Discussion}

The calculated (or estimated) chilling requirements for walnut cultivars and genotypes in 2 consecutive years are shown in Table 1. The chilling requirements were considered to be satisfied when $50 \%$ of buds reached the balloon or green tip stage. The

able 3. Heat requirement $\left(\mathrm{GDH}^{\circ} \mathrm{C}\right)$ of Persian walnut cultivars and genotypes to reach $50 \%$ of lateral and terminal buds and catkins to the balloon or green tip stage according to the Richardson et al. (1974) model in 2 successive years. ${ }^{\mathrm{z}}$

\begin{tabular}{|c|c|c|c|c|c|c|c|}
\hline $\begin{array}{l}\text { Cultivars } \\
\text { and } \\
\text { genotypes }\end{array}$ & Years & Lateral bud & Mean & Terminal bud & Mean & Catkin & Mean \\
\hline \multirow[t]{2}{*}{$\overline{Z_{30}}$} & 2006 & $10,656 \pm 86 \mathrm{~d}^{\mathrm{y}}$ & 10,512 & $11,355 \pm 177 b$ & 11,503 & $10,930 \pm 87 \mathrm{a}$ & 8,567 \\
\hline & 2007 & $10,368 \pm 137 \mathrm{~d}$ & & $11,652 \pm 216 \mathrm{de}$ & & $10,795 \pm 107 \mathrm{a}$ & \\
\hline \multirow[t]{2}{*}{$Z_{67}$} & 2006 & $11,544 \pm 233 \mathrm{~cd}$ & 12,252 & $11,950 \pm 95 b$ & 12,743 & $9,715 \pm 123 \mathrm{ab}$ & 8,680 \\
\hline & 2007 & $12,960 \pm 156 \mathrm{bc}$ & & $13,536 \pm 224 a b c$ & & $10,460 \pm 130 a$ & \\
\hline \multirow[t]{2}{*}{$Z_{53}$} & 2006 & $12,764 \pm 224 b c$ & 12,020 & $10,360 \pm 114 b$ & 11,064 & $7,930 \pm 351 \mathrm{bc}$ & 8,232 \\
\hline & 2007 & $11,276 \pm 345 \mathrm{~cd}$ & & $11,768 \pm 143 \mathrm{cde}$ & & $8,534 \pm 273 d$ & \\
\hline \multirow[t]{2}{*}{$Z_{63}$} & 2006 & $15,033 \pm 89 \mathrm{a}$ & 14,636 & $15,267 \pm 345 \mathrm{a}$ & 15,186 & $8,720 \pm 176 \mathrm{bc}$ & 9,071 \\
\hline & 2007 & $14,240 \pm 128 \mathrm{ab}$ & & $15,105 \pm 278 a$ & & $9,423 \pm 159 \mathrm{abc}$ & \\
\hline \multirow[t]{2}{*}{ Serr } & 2006 & $10,850 \pm 95 \mathrm{~d}$ & 10,753 & $11,600 \pm 380 b$ & 10,934 & $7,075 \pm 412 \mathrm{c}$ & 7,165 \\
\hline & 2007 & $10,656 \pm 122 \mathrm{~d}$ & & $10,268 \pm 97 \mathrm{e}$ & & $7,255 \pm 235 \mathrm{~d}$ & \\
\hline \multirow[t]{2}{*}{ Hartley } & 2006 & $14,192 \pm 431 \mathrm{ab}$ & 14,540 & $14,680 \pm 447 \mathrm{a}$ & 14,322 & $9,525 \pm 98 \mathrm{ab}$ & 9,647 \\
\hline & 2007 & $14,888 \pm 146 \mathrm{a}$ & & $13,965 \pm 198 \mathrm{ab}$ & & $9,770 \pm 185 \mathrm{ab}$ & \\
\hline \multirow[t]{2}{*}{ Lara } & 2006 & $11,936 \pm 167 \mathrm{~cd}$ & 12,620 & $12,150 \pm 265 b$ & 12,957 & $7,480 \pm 284 \mathrm{c}$ & 7,672 \\
\hline & 2007 & $13,305 \pm 247 \mathrm{ab}$ & & $13,765 \pm 364 a b$ & & $7,865 \pm 341 \mathrm{~cd}$ & \\
\hline \multirow[t]{2}{*}{ Pedro } & 2006 & $13,065 \pm 390 \mathrm{bc}$ & 13,142 & $14,396 \pm 84 a$ & 13,625 & $8,155 \pm 105 \mathrm{bc}$ & 8,227 \\
\hline & 2007 & $13,220 \pm 107 \mathrm{ab}$ & & $12,855 \pm 231 \mathrm{bcd}$ & & $8,300 \mathrm{~b} \pm 216 \mathrm{~cd}$ & \\
\hline Difference & 2006 & $\mathrm{a}$ & & & & & \\
\hline $\begin{array}{l}\text { between } \\
\text { years }\end{array}$ & 2007 & $\mathrm{~b}$ & & & & & \\
\hline
\end{tabular}

Table 4. Correlation coefficient of Persian walnut cultivars and genotypes between chilling treatments (hours below $7{ }^{\circ} \mathrm{C}$ ) and heat requirements for reaching to the balloon or green tip stage in 2 successive years.

\begin{tabular}{|c|c|c|}
\hline $\begin{array}{l}\text { Cultivars and } \\
\text { genotypes }\end{array}$ & Year & $\begin{array}{l}\text { Correlation } \\
\text { coefficient }^{\mathrm{z}}\end{array}$ \\
\hline \multirow[t]{2}{*}{$\overline{Z_{30}}$} & 2006 & $-0.64 * *$ \\
\hline & 2007 & $-0.86 * *$ \\
\hline \multirow[t]{2}{*}{$Z_{67}$} & 2006 & $-0.59 * *$ \\
\hline & 2007 & $-0.62 * *$ \\
\hline \multirow[t]{2}{*}{$Z_{53}$} & 2006 & $-0.87 * *$ \\
\hline & 2007 & $-0.95 * *$ \\
\hline \multirow[t]{2}{*}{$Z_{63}$} & 2006 & $-0.47 * *$ \\
\hline & 2007 & $-0.32 * *$ \\
\hline \multirow[t]{2}{*}{ Serr } & 2006 & $-0.65 * *$ \\
\hline & 2007 & $-0.63 * *$ \\
\hline \multirow[t]{2}{*}{ Hartley } & 2006 & $-0.45 * *$ \\
\hline & 2007 & $-0.31 \mathrm{NS}$ \\
\hline \multirow[t]{2}{*}{ Lara } & 2006 & $-0.33 * *$ \\
\hline & 2007 & $-0.62 * *$ \\
\hline \multirow[t]{2}{*}{ Pedro } & 2006 & $-0.53 * *$ \\
\hline & 2007 & $-0.52 * *$ \\
\hline
\end{tabular}

$\mathrm{z}_{\mathrm{NS}}$ and $* *=$ nonsignificant and significant at $1 \%$ statistical level, respectively $(P \leq 0.01)$. 

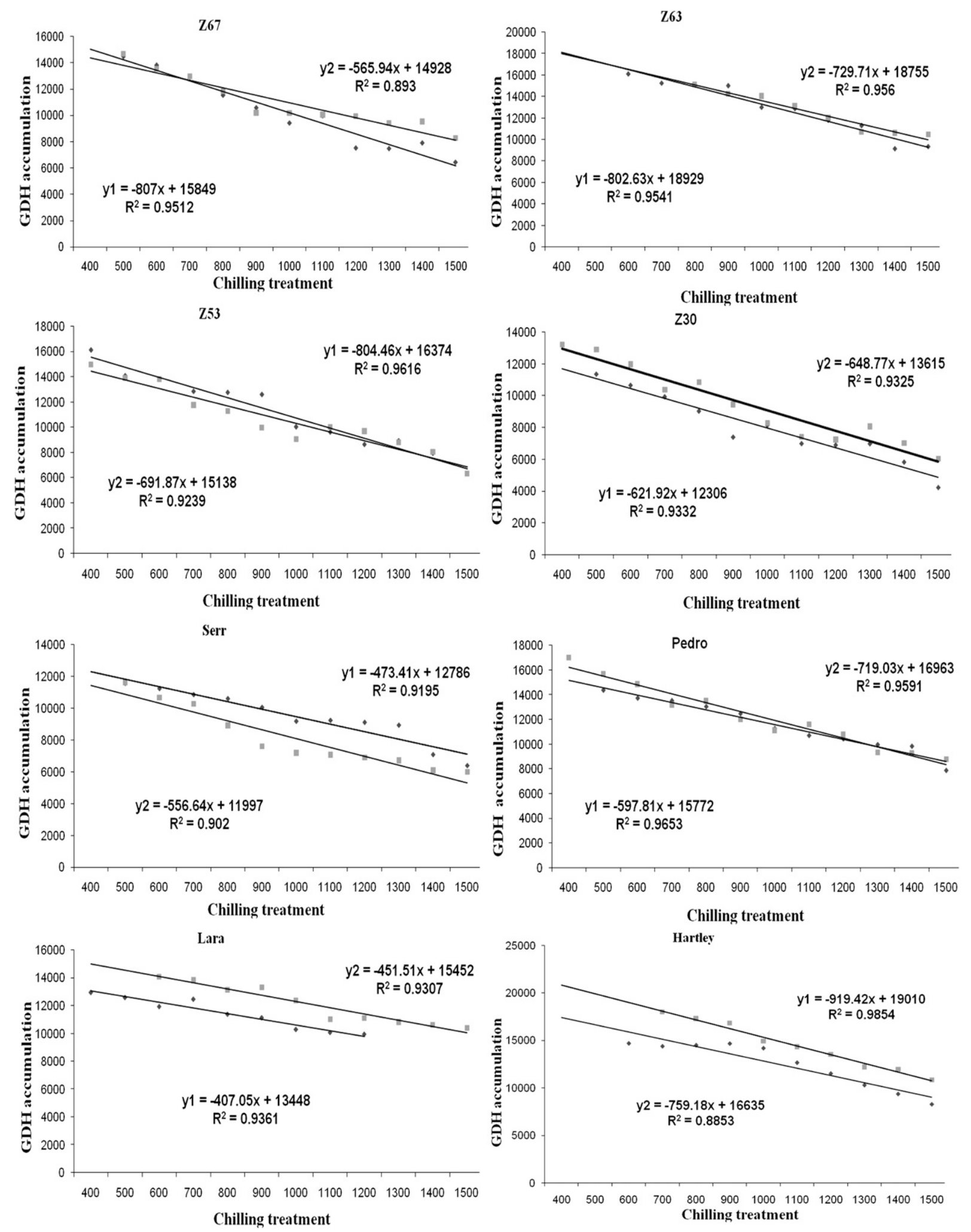

\section{$\diamond$ first year $\quad$ second year}

Fig. 1. The correlation between mean heat requirement and chilling treatments for all types of buds and catkin of Persian walnut cultivars and genotypes in 2 successive years along with the regression functions and coefficient of determination. Detached (or excised) twigs exposed to various chilling temperatures from 400 to 1500 and were forced to grow at $20^{\circ} \mathrm{C}$. The growing degree hours $\left(\mathrm{GDH} ;{ }^{\circ} \mathrm{C}\right)$ was calculated by the difference of 20 from $4.5^{\circ} \mathrm{C}$ in 2 years.

chilling requirements of catkins were lower than lateral and terminal buds. The chilling requirements were lowest for catkins, except in 'Serr' and 'Lara', and highest for lateral

HortScience Vol. 44(3) June 2009 buds. This exception for these cultivars refers to the genetic characteristics. The chilling requirements ranged from 400 to $750 \mathrm{~h}$ for catkins, 550 to $950 \mathrm{~h}$ for terminal buds, and
650 to $1000 \mathrm{~h}$ for lateral buds. These results are in accordance with the hypothesis that terminal buds required less chilling temperatures than the lateral buds (Scalabrelli and 
Couvillon, 1986). 'Serr' and ' $Z_{30}$ ' had the lowest chilling requirements $(650$ and $650 \mathrm{~h}$, respectively). ' $Z_{67}$ ', 'Pedro', ' $Z_{53}$ ', ' $Z_{63}$ ', and 'Lara', with 750, 750, 800, 900, and 900 h, respectively, showed intermediate chilling requirements. Finally, 'Hartley' with 1000-h chilling requirement of terminal, lateral, and catkin bud dormancy, was the walnut cultivar with the highest chilling requirement in this study. The range of chilling requirements (for breaking buds and catkins dormancy) in the studied cultivars and genotypes varied from 650 to $1000 \mathrm{~h}$. These results are in accordance with the suggestion of Chandler et al. (1937), who estimated the chilling requirement of walnut cultivars between 400 and $1500 \mathrm{~h}$ below $7{ }^{\circ} \mathrm{C}$.

The higher chilling requirements in the cultivars indicated the risk of losses in yield or having low production growing these cultivars in the warmer regions (Erez, 2000). Based on the results, 'Serr' and ' $Z_{30}$ ' seem to be more suitable to cultivate in warmer winter climates. Alternatively, 'Hartley' might be the appropriate cultivar for cultivation in colder regions and especially with the risk of late spring frosts. Among the Iranian-evaluated genotypes, ' $\mathrm{Z}_{63}$ ' seems to be more adapted to produce good yield in colder winter climates too. Although late-flowering cultivars had usually higher heat requirements, the flowering time is mainly determined by the chilling requirements. Therefore, when late-leafing walnut cultivars and genotypes are used in breeding programs for cultivation in cold climates with early spring or late winter frost, the progenies with high chilling requirements from parents like 'Hartley' and ' $Z_{63}$ ' could be crossed with them.

According to results, the cultivars and genotypes with similar chilling requirements showed different responses to chilling. For example, ' $Z_{30}$ ' and 'Serr' or ' $Z_{63}$ ' and 'Lara' had similar chilling requirements, but ' $Z_{30}$ ' and 'Lara' showed a higher percentage $(80 \%$ or greater) of budbreak in a wide range of chilling accumulation treatments compared with ' $Z_{67}$ ' and ' $Z_{63}$ ', respectively (Table 2 ). On the other hand, these cultivars and genotypes needed more chilling to reach a higher percentage of budbreak compared with their chilling requirement.

The heat requirement for lateral and terminal buds and catkins was calculated by Richardson et al. (1974). The cultivars and genotypes were classified into three groups in accordance with their heat requirements: low (' $Z_{30}$ ' and 'Serr'), medium (' $Z_{53}$ ', ' $Z_{67}$ ', 'Lara', and 'Pedro'), and high heat requirement ('Hartley' and ' $\mathrm{Z}_{63}$ ') (Table 3). Our results indicated that, except for ' $Z_{30}$ ', the heat requirements for catkins were lower than lateral and terminal buds and, except in 'Hartley' and ' $\mathrm{Z}_{53}$ ', GDH ${ }^{\circ} \mathrm{C}$ accumulation for terminal buds was higher than lateral buds (Table 3 ). This observation was also observed in other experiments (Citadin et al., 2001; Gariglio et al., 2006). ' $Z_{63}$ ' and 'Lara' had similar chilling requirements, but their heat requirements were different; however, in other cultivars and genotypes, there was a positive correlation between chilling and heat requirements. The results derived from this work as well as obtained by others (Brown, 1957; Spiegel-Roy and Alston, 1979; Swartz and Powell, 1981) indicated that this situation could be the result of residual effects of dormancy.

The time of bloom depends on the heat requirement of the cultivars $\left(\mathrm{GDH}{ }^{\circ} \mathrm{C}\right.$ accumulation) during endodormancy (Arnold, 1959; Citadin, 1999). Furthermore, among promising genotypes, ' $Z_{63}$ ' seems to be appropriate for cultivation in the regions with late winter or early spring frosts. Among the cultivars, 'Serr' with the lowest heat requirement is unsuitable for such a climate, but 'Hartley' was the best for the region with late winter or early spring frosts.

According to the earlier researches, dormancy and subsequently chilling requirements are affected by atmospheric and soil condition such as temperature (Welling, 2003), nutrition (Almond and Young, 1990), light, rainfall (Buchanan et al., 1977), and water stress and could change in different years. We also observed 100- to 200-h differences in the chilling and heat requirements in 2 successive years in the same cultivars, which indicates the environmental factors affected the chilling and heat requirements in 2 successive years (Tables 1 and 3 ).

There was a negative correlation between chilling treatments for breaking dormancy and heat requirements in walnut cultivars and genotypes (Table 4). These coefficients were negative and high except in 'Hartley', 'Lara', and ' $Z_{63}$ ' that imply the prolonged exposure to chilling temperatures, when dormancy is overcome, could reduce the heat requirement for budbreak. These results confirm that resting or partially chilled trees require much more heat accumulation in comparison with the trees in which their chilling was satisfied before they were able to bloom (Richardson et al., 1975; Samish, 1954; Swartz and Powell, 1981). In contrast, extra chilling given after completion of rest reduces the needed heat unit accumulation for blooming (Citadin et al., 2001; Couvillon and Erez, 1985; Couvillon and Hendershott, 1974; Felker and Robitaille, 1985; Scalabrelli and Couvillon, 1986). Monet and Bastard (1971) demonstrated that peach flower buds develop slowly under low temperature but are physiologically and biochemically active. Rapid growth resumes when temperatures rise. Thus, prolonged exposure to low temperature prolongs the slow growth phase, thereby reducing the rapid growth phase. Among the cultivars and genotypes, 'Serr' and ' $\mathrm{Z}_{53}$ ' had the highest correlation coefficients, respectively. The results also indicated that except for ' $Z_{63}$ ', correlation coefficient of domestic walnut-promising genotypes were higher than cultivars. Meanwhile, heat requirements of promising genotypes were more affected by increasing chilling treatments.

The correlation between mean heat requirement and chilling treatments for all types of buds and catkins in 2 successive years along with the regression functions for 2 years $\left(\mathrm{y}_{1}\right.$ and $\left.\mathrm{y}_{2}\right)$ and coefficient of determination are shown in Figure 1 for each cultivar and genotype. Based on the linear function with excising chilling time, the synchronism of budbreak will increase and the heat requirements of cultivars and genotypes will modify by prolonged chilling. These results are in agreement with the findings of Couvillon and Erez (1985), who found that when cultivars with low chilling requirements cultivated together with cultivars with high chilling requirements in the same field condition, they must show lower heat requirements too. Because the excessive chill causes $90 \%$ of the heat requirement variations, in consequence, the cultivar shows no specific heat requirements. Several other studies have shown that the heat requirements of cultivars and genotypes can be modified by a continuous chilling accumulation after the breaking of dormancy (Couvillon and Hendershott, 1974; SpiegelRoy and Alston, 1979; Swartz and Powell, 1981).

In conclusion, chilling treatment increases the percentage of budbreak and decreases the heat requirement in the cultivars and genotypes, but the responses of cultivars and genotypes and different buds to the chilling treatments are not similar. Figure 1 is a more appropriate model to study the heat requirement during increasing a chilling period in various cultivars and genotypes. Also, the estimated chilling and heat requirements (Tables 1 and 3) are good predictors for time of budbreak, but should be used in appropriate areas. The domestic Iranian genotypes are also suitable for a range of different climates from warm climates (' $\mathrm{Z}_{30}$ ') to cold areas (' $\mathrm{Z}_{63}$ ').

\section{Literature Cited}

Almond, M.A. and E. Young. 1990. Growth and protein content of apple in response to shoot and root temperature following chilling. HortScience 22:371-377.

Arnold, C.Y. 1959. The determination and significance of the base temperature in linear heat unit system. Proc. Amer. Soc. Hort. Sci. 74: 430-445.

Bianchi, V.J., J.J.P. Arruda, J.G.C. Júnior, and F.G. Herter. 2000. Studo da paradorméncia em Pereira por meio do método biológico. Revista Brasileira de Fruitcultura. 22:294-296.

Black, M.W. 1952. The problem of prolonged rest in deciduous fruit trees. Proc. 13th Intl. Hort. Cong. Vol. 2. London. p. 1122-1131.

Brown, D.S. 1957. The rest period of apricot flower buds as described by a regression of time of bloom on temperature. Plant Physiol. 32:7585.

Buchanan, D.W., J.F. Bartholic, and R.H. Biggs. 1977. Manipulation of bloom and ripening dates of three Florida grown peach and nectarine cultivars through sprinkling and shade. J. Amer. Soc. Hort. Sci. 102:466-470.

Camelatto, D., G.R. Nachtigall, J.J.P. Arruda, and F.G. Herter. 2000. Efeitos de flutuações de temperatura, horas de frio hibernal e reguladores de crescimento no abortamento de gemas 
florais de Pereira. Revista Brasileira de Fruticultura 22:111-117.

Chandler, W.H., M.H. Kimball, G.L. Phillip, W.P. Tufts, and G.P. Weldon. 1937. Chilling requirements for opening of buds on deciduous orchard trees and some other plants in California. Cal. Agr. Expt. Bul. 611.

Citadin, I. 1999. Necessidade de calor para antese e brotação em pessegueiro [Prunus persica $(\mathrm{L}$.) Batsch], Univ. Federal de Pelotas, Pelotas, Brazil. MSc Diss.

Citadin, I., M.C.B. Raseira, F.G. Herter, and J.B. da Silva. 2001. Heat requirement for blooming and leafing in peach. HortScience 36:305-307.

Citadin, I., M.C.B. Raseira and A.C. Quezada. 1998. Substrato para conservação de ramos destacados de pessegueiro, Prunus persica L. (Batsch). A gropecuária de clima Temperado 1:55-59.

Couvillon, G.A. and A. Erez. 1985. Influence of prolonged exposure to chilling temperatures on bud break and heat requirement for bloom of several fruit species. J. Amer. Soc. Hort. Sci. 110:47-50.

Couvillon, G.A. and H. Hendershott. 1974. A characterization of the after-rest period of two peach cultivars of different chilling requirements. J. Amer. Soc. Hort. Sci. 99:23-26.

Coville, F.V. 1920. The influence of cold in stimulating the growth of plants. J. Agr. Res. 20:151-192.

Dietrichson, J. 1964. The selection problem and growth rhythm. Silvae Genet. 13:178-184.

Erez, A. 2000. Bud dormancy; phenomenon, problems and solution in the tropic and subtropic, $\mathrm{p}$. 17-48. In: Erez A. (ed.). Temperate fruit crops in warm climates. Kluwer Academic Publisher, Dordrecht, The Netherlands.

Erez, A., G.A. Couvillon, and C.H. Hendershott. 1979. The effect of cycle length on chilling negation by high temperatures in dormant peach leaf buds. J. Amer. Soc. Hort. Sci. 104:573-576.

Faust, M., A. Erez, L.J. Rowland, S.Y. Wang, and H.A. Norman. 1997. Bud dormancy in perennial fruit trees: Physiological basis for dor- mancy induction, maintenance and release. HortScience 32:623-629.

Felker, F.C. and H.A. Robitaille. 1985. Chilling accumulation and rest of sour cherry flower buds. J. Amer. Soc. Hort. Sci. 110:227-232.

Fennell, A. 1999. Systems and approaches to studying dormancy: Introduction to the workshop. HortScience 34:1172-1173.

Fuchigami, L.H., H.A. Weiser, and H.A. Evert. 1971. Induction of cold acclimation in Cornus stolonifera Michx. Plant Physiol. 47:98-103.

Gariglio, N., D.E. Gonza'lez, M. Mendow, C. Reig, and M. Agusti. 2006. Effect of artificial chilling on the depth of endodormancy and vegetative and flower budbreak of peach and nectarine cultivars using excised shoots. Scientia Hort. 108:371-377.

Herter, F.G., I. Citadin, and C.A.P. Silveria. 2000. Necessidade de calor para a antese em pessegueiro avaliada pelo método de ramos destacados. Agropecuária Clima Temperado 3:253-259.

Herter, F.G., R. Rageau, M. Bonhomme, and J.C. Mauget. 1992. Determinação do término da dorméncia e floração para algumas cultivares de macieira: Comparação entre métods biológicos e empirico. Revista Brasileira de Fruticultura 14:77-81.

Hill, J., H.C. Becker, and P.M.A. Tigerstedt. 1998. Quantitative and ecological aspects of plant breeding. St. Edmundsbury Press, Suffolk, UK.

Irving, R.M. and F.O. Lamphear. 1967. Environmental control of cold hardiness in woody plants. Plant Physiol. 42:1191-1196.

Molisch, H. 1908. Ube rein einfaches varfahren, Pflanzen Zutrein sitzungsber. Akad. Wiss. Wien. Math.-Nat. K1. Abt. 117:87-116.

Monet, R. and Y. Bastard. 1971. Effets d'une temperature modérément élevée: $25 \mathrm{C}^{\circ}$, sur les bourgeons floraux du pécher. Physiol. Veg. 9:209-226.

Raseira, M.C.B. 1986. Time of flower bud initiation and meiosis in peach cultivars differing in chilling requirement. Univ. of Arkansas, Fayetteville, PhD Diss.
Richardson, E.A., S.D. Seeley, and D.R. Walker. 1974. A model for estimating the completion of rest of 'Redhaven' and 'Elberta' peach trees. HortScience 9:331-332.

Richardson, E.A., S.D. Seely, D.R. Walker, J.L.M. Anderson, and G.L. Ashcroft. 1975. Phenoclimatography of spring peach bud development. HortScience 10:236-237.

Ruck, H.C. 1975. Deciduous fruit tree cultivars for tropical and subtropical regions. Hort. Rev. No. 3. Common Wealth Agricultural Bureaux, Slough, UK. p. 91.

Samish, R.M. 1954. Dormancy in woody plants. Plant Physiol. 5:183-204.

S.A.S. Institute Inc. 2002. SAS user's guide: Statistics. Version 9. 1st EdCary, NC.

Scalabrelli, G. and G.A. Couvillon. 1986. The effect of temperature and bud type on rest completion and the GDH requirement for bud break in 'Redhaven' peach. J. Amer. Soc. Hort. Sci. 111:537-540.

Scorza, R. and W.R. Okie. 1990. Peaches (Prunus persica L. Batsch). Acta Hort. 290:177-231.

Spiegel-Roy, P. and F.H. Alston. 1979. Chilling and post-dormant heat requirement as selection criteria for late-flowering pears. J. Hort. Sci. 54:115-120.

Swartz, H.J. and L.E. Powell, Jr. 1981. The effect of long chilling requirement on time of bud break in apple. Acta Hort. 120:173-178.

Valentini, N., G. Me, R. Ferrero, and F. Spanna. 2001. Use of bioclimatic indexes to characterize phenological phases of apple varieties in northern Italy. Intl. J. Biometeorol. 45:191-195.

Weinberger, J.H. 1950. Chilling requirements of peach varieties. Proc. Amer. Soc. Hort. Sci. 56:122-128.

Weldon, G.P. 1934. Fifteen years study of delayed foliation of deciduous fruit trees in southern California. Calif. Agr. Bull. 23:160-181.

Welling, A. 2003. Overwintering in woody plants: Involvement of ABA and dehydrins. Institute of Biotechnology and Department of Biosciences, Division of Genetics Faculty of Science, University of Helsinki, Finland. p. 159. 